\title{
Review of Cathode Materials for Solid Oxide Fuel Cell
}

\author{
${ }^{1}$ B. S. Kamble*, ${ }^{2}$ V. J . Fulari, ${ }^{3}$ R. K. Nimat \\ ${ }^{1}$ Department of Physics, D. B. J. College, Chiplun-415605, India \\ ${ }^{2}$ Department of Physics, Shivaji University, Kolhapur-416004, India \\ ${ }^{3}$ Department of Physics, Balasaheb Desai College, Patan-415206, India \\ *Corresponding Author: kamblebabaso@yahoo.com
}

Available online at: www.isroset.org

Received: 25/Oct/2018, Accepted: 21/Nov/2018, Online: 31/Dec/2018

\begin{abstract}
Proper selection of cathode material for solid oxide fuel cell (SOFC) is more important because of its impact which is noticeable on the performance of SOFC. The cathode is exposed to high temperature and an oxidizing atmosphere which limits the choice of metals and conducting oxides. Normally most common materials for SOFC cathodes belong to the family of the perovskite-type oxides. Cathode material should exhibit high electronic conductivity, high catalytic activity towards the oxygen reduction, it is able to conduct electrons as well as oxide ions, and have a porous microstructure to allow transport of oxygen. Its thermal expansion coefficient should match with that of other components. The most commonly used cathode for SOFCs is $\mathrm{La}_{1-\mathrm{x}} \mathrm{Sr}_{\mathrm{x}} \mathrm{MnO}_{3-\delta}(\mathrm{LSM})$.

Keywords- Cathode, LSM, SOFC.
\end{abstract}

\section{INTRODUCTION}

In this world, of increasing industrialization requires sustainable, highly efficient, non polluted energy production. There is necessity of clean, pollution free, most efficient and versatile technology for generation of electrical energy. The application of the fuel cell technologies may be one of the most important technological developments in the next decades. A fuel cell operating as a sort of continuously, replenished battery provides an alternative, where by electrical energy can be made available with low levels of $\mathrm{NO}_{x}$ and $\mathrm{SO}_{\mathrm{x}}$ emissions. Among the different types of fuel cells, solid oxide fuel cell (SOFC) offers clean, pollution free, most efficient and versatile technology for chemical electrical energy conversion. But selection of cathode material for SOFC is more important because proper cathode material enhances the efficiency of SOFC. Most commonly used cathode material for SOFC is $\mathrm{La}_{1-\mathrm{x}} \mathrm{Sr}_{\mathrm{x}} \mathrm{MnO}_{3-\delta}(\mathrm{LSM})$.

Fuel Cell: - The fuel cell concept has been known from the $19^{\text {th }}$ century itself when Sir William Grove invented that electricity can be generated by reverse process of electrolysis of water. Grove, in his work, proposed that when two platinum electrodes are immersed in $\mathrm{H}_{2} \mathrm{SO}_{4}$, with other terminals individually insulated in containers of $\mathrm{O}_{2}$ and $\mathrm{H}_{2}$ with passing a constant current between the electrodes.
Grove invented that number of these electrodes sets were connected in series of combination and electricity can be generated by combining hydrogen and oxygen. He gives it the name 'gas voltaic battery' and it was the first fuel cell. Fuel Cell has tremendous applications on a traditional power generation systems.

A fuel cell is explained as; it is device as converting energy and produces electricity by collecting fuel as an input. When we supply a fuel continuously, a fuel cell starts to produces electricity. Fuel cell and battery are not similar because of not continuously supply fuel to the battery same as fuel cell. But a fuel cell did not consume when it generate electric power ${ }^{[1]}$.

Basic Operation of Fuel Cell: A fuel cell is an electrochemical conversion device which converts chemical energy directly into electrical energy. It produces electricity from fuel on the anode side and an oxidant on the cathode side, which react in the presence of an electrolyte. The basic building block of a fuel cell consists of an electrolyte layer in contact with an anode and cathode on either side. In a typical fuel cell, fuel is fed continuously to the anode and an oxidant, often oxygen from air, is fed continuously to the cathode. The electrochemical reactions take place at the electrodes to produce ionic conduction through the electrolyte, while driving a complementary electric current that performs work on the load. 
Fuel cells are classified according to the choice of electrolyte and fuel, which in turn determine the electrode reactions and the type of ions that carry the current across the electrolyte.

- Alkaline fuel cell (AFC)

- $\quad$ Phosphoric acid fuel cell (PAFC)

- Molton carbonate fuel cell (MCPC)

- $\quad$ Solid oxide fuel cell (SOFC)

- $\quad$ Proton exchange membrane fuel cell (PEMFC)

- Direct methanol fuel cell (DMFC)

- $\quad$ Regenerative fuel cell (RFC)

- $\quad$ Zinc air fuel cell (ZAFC)

Among these types of fuel cells much development has been focused on solid oxide fuel cell (SOFC) technology, because of its many advantages over the conventional power generation system. These are high efficiency, reliability, modularity, fuel adaptability and very low levels of NOx and SOx emissions. The solid oxide fuel cell (SOFC) offers clean, pollution-free, most efficient and versatile technology for chemical to electrical energy conversion.

Solid Oxide Fuel Cell (SOFC):- The operating mechanism of fuel cells is electrochemical reaction between reactants to generate electricity. It does not require intermediate energy conversion steps unlike other electric power generation devices such as internal combustion engines. Fuel cells can operate on conditions that as both oxidant and fuel are supplied to the electrodes ${ }^{[2]}$. Department of energy projected that the primary energy use will increase by 31 percent over next 25 years. For progression of SOFC it is desired that it may high-efficient, fuel-versatile and offers clean energy. SOFC consists of anode, cathode and electrolyte and it directly converts chemical energy to electrical energy with any type of combustion. In addition, SOFCs can be directly operated on a full range of practical hydrocarbon fuels such as natural gas, methanol, waste biogas, diesel etc. due to its high operating temperatures and tolerance to $\mathrm{CO}$ Furthermore SOFCs minimizes high levels of $\mathrm{NO}_{\mathrm{x}}$ and $\mathrm{SO}_{\mathrm{x}}$ emission associated with traditional energy conversion systems ${ }^{[3]}$. The SOFC is highly efficient and simple fuel cell compared to engines and advanced thermal power generation sources. It minimizes environmental impact and can at least partially internally amend hydrocarbon fuel ${ }^{[2]}$. SOFCs can be characterized with its solid ceramic components, especially solid electrolyte, which is a composite oxide. Traditional SOFCs operate at high temperature approximately $800^{\circ} \mathrm{C}-1000^{\circ} \mathrm{C}$. This high operating temperature allows internal reforming, promotes rapid electro catalysis with the need for precious metals such as platinum, and produces high quality heat which can be used for combined heat processor to increase the efficiency even further. At the anode side, the hydrocarbon fuel is catalytically converted into carbon monoxide, and then electrochemically reacts to produce water and carbon dioxide. Only a few materials can tolerate the high temperature and out of these materials most of them are expensive and not suitable for mass production ${ }^{[4]}$.

\section{FUNDAMENTAL OF SOFC}

The first solid oxide fuel cell (SOFC) was designed by Baur and Preis in 1937 which was operated at $1000^{\circ} \mathrm{C}^{[5]}$, after that Nerst invented solid electrolytes in 1899. The SOFCs mainly consists of an anode, a cathode, an electrolyte and interconnect. Both interfaces between the cathode and an electrolyte and between anode and an electrolyte are exposed to oxygen or hydrogen gas. Two chemical reactions occur. The oxygen gas travels through porous cathode and react with electrons to form oxygen ions. This oxygen reduction process takes place at the cathode/electrolyte interface and these ions react with hydrogen and produces water, electrons and heat. This reaction is hydrogen oxidation. The produced free electrons on the anode side will travel to the cathode along with the external circuit. The free electrons and oxygen gas will start the cathodic reaction for the next cycle. In this manner, the SOFC converts electrochemical energy into electrical power.

Principle and Operation of SOFC: A SOFC essentially consists of two electrodes cathode and anode which are separated by a dense oxygen ion conducting electrolyte. On the anode side fuel is continuously sucked and oxidized, while on the cathode side oxygen is reduced. This creates an oxygen concentration gradient across the electrolyte, which attracts oxygen ions from the cathode side to the anode side where they react with the fuel to release electrons to the anode. These electrons pass through an external circuit back to the cathode, thereby maintaining overall electrical charge balance and produces an electric current.

\section{REQUIREMENT OF COMPONENTS FOR SOFC}

1) Appropriate stability.

2) Suitable conductivity.

3) Chemically match with other component.

4) Porous permits gas transport to the reaction sites.

5) High catalytic activity.

6) Low cost

The most common type of cathode material is perovskite based $\mathrm{LaMnO}_{3}$. Furthermore strontium is normally used to dope with $\mathrm{LaMnO}_{3}$ and it become $\mathrm{La}_{1-\mathrm{x}} \mathrm{Sr}_{\mathrm{x}} \mathrm{MnO}_{3-\delta}$ (LSM) which can enhance the electronic conductivity. The thermal expansion coefficient of LSM matches well with that of YSZ ${ }^{[6]}$, however its conductivity is relatively low.

\section{APPLICATIONS OF SOFC}


- High power reliability: computer facilities, call centers communication facilities, data processing centers high technology manufacturing facilities.

- Emission minimization or elimination: Urban areas, industrial facilities, airports, zones with strict emission standards.

- Biological waste gases are available: Waste treatment plants, SOFC can convert waste gases to electricity and heat with minimal environment intrusion.

- Limited access to utility grid: Rural or remote areas, maximum grid capacity.

Cathode materials: The operating temperature of SOFC is high, therefore for SOFC cathode, electronic conducting oxides or noble metals can be used. Noble metals are expensive and insufficient to long term stability, so it is unsuitable for practical applications ${ }^{[7]}$. Several hetrometallic oxides have been proposed and tested. Perovskite type lanthanum strontium manganite (LSM) provide good performance at operating temperatures above $800^{\circ} \mathrm{C}$ and offer excellent thermal expansion match with that of electrolyte material ${ }^{[8]}$. A cathode material in a SOFC has to exhibit several properties.(1) high electronic conductivity $\left(>100 \mathrm{~S}_{\mathrm{Cm}}^{-1}\right),(2)$ non-negligible anionic (oxygen) conductivity $\left(10^{-1}{\left.\mathrm{~S} . \mathrm{cm}^{-1}\right)}^{-1}\right.$ and chemical stability under fuel cell operating conditions, in particular in contact with the electrolyte. The compatibility with respect to the electrolyte refers not only to chemical inertness both during operation and preparation, but also to the thermo mechanical properties of the two materials in contact, with the expansion coefficients have to be similar.

\section{SELECTION OF CATHODE MATERIAL}

As compared with other types of fuel cell main advantage of SOFC is its tolerance to the impurities of inlet fuels; this means various type of fuel cell can be applied with SOFC. It is noted that the fuel flexibility is mainly due to its high operating temperature. However, at its high operating temperature there are some limitations of SOFC especially with the materials it used. There are many researchers who develop and fabricated materials to meet requirement of SOFC ${ }^{[9]}$. For proper function as a cathode in SOFC, the material should have a high electro catalytic activity towards oxygen reduction and high chemical stability in oxidizing environment without forming highly resistive reaction products with the electrolyte and current collector $^{[10,11]}$. The material should exhibit similar thermo mechanical properties as the electrolyte to avoid stresses to develop upon heating and cooling, and it should have high electrical conductivity.

The cathode materials used in SOFC must exhibit certain following characteristics.
1) Inexpensive and easy fabrication

2) Phase and microstructure remain same after operation

3) Chemical structure remains same.

4) Both ionic and electronic conductivity must high.

5) Microstructure of cathode material must be porous.

The selection of cathode material will depend on the low operating temperature, specific ceramic electrolyte material and various fabrication methods are used. Cathode materials of SOFC are manufactured as a porous structure to allow rapid mass transport of reactant and product gases ${ }^{[12]}$. The air electrolyte operates the oxygen to reduce it at $1000^{\circ} \mathrm{C}$ in atmosphere. SOFC cathode materials must show high electronic and ionic conductivity, sufficient chemical and thermal stability at high temperature in air, and also good compatibility with that of electrolyte. Cathode material should have sufficient porous to pass oxygen from the gas phase to the air electrode / electrolyte interface.

Lanthanum manganite $\left(\mathrm{LaMnO}_{3}\right)$ suitably doped with alkaline earth element which were met to satisfy the required condition of cathode material ${ }^{[13]}$. Because of hopping of an electron hole between $3^{+}$and $4^{+}$valence states of manganese the lanthanum manganite display the electronic conductivity. By doping with a divalent ion like strontium this conductivity is enhanced ${ }^{[14]}$. Perovskite structured lanthanum strontium manganite (LSM) are normally used as cathode materials for SOFC because they provide good performance at operating temperature above $800^{\circ} \mathrm{C}$ and offer excellent thermal expansion matches with zirconia electrolytes ${ }^{[12]}$. Furthermore, the reactivity and the inter diffusion between doped lanthanum manganite and yittria stabilized zirconia electrolyte have shown minimal interactions between these two materials at $1000^{\circ} \mathrm{C}$.

\section{CONCLUSION}

Solid oxide fuel cell (SOFC) is a device to obtain electrical energy from chemical energy with minimal emissions. Conventional SOFCs operate at high temperature range $800^{\circ} \mathrm{C}-1000^{\circ} \mathrm{C}$. To reduce the operating temperature, it is essential that the proper choice of cathode is made for SOFC. Strontium doped lanthanum manganite is a promising cathode material for proper operation of SOFC. Many research groups have synthesized LSM material in bulk form. The solid oxide fuel cell technology has been hindered due to high operating temperatures of fuel cell. The operating temperature of solid oxide fuel cell can be reduced by synthesizing fuel cell material in thin film form. Due to excellent thermal expansion matching with zirconia electrolytes LSM thin films perovskite structured lanthanum strontium manganite (LSM) are the most often used cathode materials for SOFC. A strontium doped lanthanum manganite (LSM), is a compromise between performance, stability, and easy of fabrication. LSM is a good electronic 
and ionic conduction material which is suitable for SOFC cathode.

\section{REFERENCES}

[1] D. Ingenieur, Nanoparticulate Cathode Films for Low temperature Solid Oxide FCs, Ph.D. thesis

[2] Y. Zhang "Synthesis and Characterization of Nanostructured Electrodes for Solid Ionic Devices", Ph.D. Thesis, Georgia Institute of Technology December 2006.

[3] S. C. Singhal, MRS Bull. 16(2006) 25

[4] J. Y. Texas, "Nanostructured Thin films for Solid Oxide fuel Cells', Ph.D. thesis A \& M University December 2008.

[5] A. Giesber 'Development of cathodes for low temperature SOFC, M.Sc. Thesis, University of Twente Feb.2004

[6] J.Fergus, Materials challenges for solid oxide fuel cells, Journal of minerals, metals and materials society, vol.59, pp-56-62,2007

[7] Neugen Q. M. J. Am. ceram. Soc. 76(3); (1993) 563.

[8] A. B. Stambouli, E. Traversa, Renewable and sustainable Energy Reviews. 6(2002) 433.

[9] R. Bove, "Solid Oxide Fuel Cell: Principles, Designs and state of art in industries, in recent trends in fuel cell science and technology; vol.267-285, S Basu, Ed: springer New York (2007) 267.

[10] T. Nakamura, G. Petzow, L. J. Gauckler, Mat. Research Bull., 14 [5] (1979) 649.

[11] Mitterdorfer, L. J. Gauckler, 'Solid State Ionics 111, [3-4] (1998) 185.

[12] H. K. Woodward 'A performance based, multi-process cost model for solid oxide fuel cells" Thesis, M.Sc. Worcester polytechnic Institute, May. 2003

[13] J. Molenda, Materials science. Poland, vol.24, 2006

[14] M. M. Gonzalezcuena 'Novel anode materials for solid oxide fuel cells, Ph.D. Thesis, university of twente, August-2002. 